\title{
GAME INTERAKTIF MENCEGAH TERJADINYA PEMANASAN GLOBAL UNTUK ANAK
}

\author{
Aryati Wuryandari \\ Fakultas Ilmu Komputer, Program Studi Teknik Informatika \\ Universitas Widya Dharma Klaten \\ Email: aryatiwibowo@gmail.com \\ Muknirotun Akmaliyah \\ Fakultas Ilmu Komputer, Program Studi Manajemen Informatika \\ Universitas Widya Dharma Klaten \\ Email: muknirotun@gmail.com
}

\begin{abstract}
ABSTRAK
Pemanasan global merupakan kenaikan suhu bumi yang diakibatkan oleh meningkatnya kosentrasi gas rumah kaca akibat dari ulah dan aktifitas manusia. Banyak sekali kerusakan yang diakibatkan oleh pemanasan global diantaranya meningkatnya air permukaan laut sampai dengan kepunahan makluk hidup. Kesadaran dan kepedulian untuk menindak lanjuti sangat diperlukan untuk menyikapi akibat dari pemanasan global. Pembelajaran tentang pemanasan global kepada anak sejak usia dini menjadi salah satu solusi dalam menanamkan kesadaran dan kepedulian terhadap lingkungan. Salah satu cara menanamkan kesadaran akibat dari pemanasan global dan pentingnya memelihara bumi ini dapat ditanggulangi dengan memberikan pembelajaran berbasis game interaktif yang menyenangkan buat anak. Game interaktif mencegah pemanasan global dibuat dengan menggunakan Adobe Flash CS 5 dan menggunakan Action Script 3.0. Diharapkan kesadaran anak - anak untuk mencintai dan melestarikan lingkungan akan muncul dari pembelajaran tersebut sehingga pemanasan global dapat dicegah sedini mungkin.
\end{abstract}

Kata kunci: pemanasan global, game, action script 3.0, adobe flash cs 5.

\begin{abstract}
Global warming is a global temperature increase caused by rising concentrations of greenhouse gases resulting from the actions and human activities. Lots of damage caused by global warming include rising sea surface water up to the extinction of a living creature. Awareness and concern for the follow-up are needed to address the consequences of global warming. Learning about global warming to children from an early age became one of the solutions to create awareness and concern for the environment. One way to create awareness as a result of global warming and the importance of maintaining this earth can be overcome by providing an interactive game based learning fun for children. Interactive games to prevent global warming created using Adobe Flash CS 5 and using Action Script 3.0. Expected awareness of children - children to love and protect the environment will emerge from this lesson so that global warming can be prevented as early as possible.
\end{abstract}

Keywords: global warming, game, action script 3.0, adobe flash cs 5.

\section{PENDAHULUAN}

Pemanasan global merupakan proses naiknya suhu rata-rata atmostfer, laut serta daratan bumi. Kenaikan suhu bumi ini diakibatkan oleh meningkatnya konsentrasi gas rumah kaca akibat dari ulah dan aktifitas manusia [1]. Dengan adanya pemanasan global banyak sekali kerusakan yang ditimbulkan tidak hanya satu tetapi bisa mencapai seluruh struktur yang berada di bumi ini [2]. Kenaikan suhu secara global akan menimbulkan banyak perubahan seperti halnya menyebabkan cuaca ekstrem dan menaikkan tinggi permukaan air laut, punahnya berbagai macam hewan, berpengaruh terhadap hasil pertanian, hilangnya gletser dan mencairnya es di kutub utara dan selatan [3].

Game merupakan aplikasi yang banyak diminati semua kalangan, terutama bagi anak-anak maupun orang dewasa. Game dapat dijadikan sebagai media interaktif dalam melakukan pembelajaran [4]. Oleh karena itu salah satu cara menanamkan kesadaran akibat dari pemanasan global dan pentingnya memelihara bumi ini dapat ditanggulangi dengan memberikan pembelajaran berbasis game interaktif yang menyenangkan bagi anak. 
Diharapkan kesadaran anak untuk mencintai dan melestarikan lingkungan akan muncul dari pembelajaran tersebut sehingga pemanasan global dapat dicegah sedini mungkin.

\section{TINJAUAN PUSTAKA}

Game merupakan sesuatu yang digunakan untuk bermain yang dimainkan dengan aturan-aturan tertentu. Dalam permainan ada yang menang dan ada yang kalah [5]. Game merupakan permainan yang menggunakan media elektronik berbentuk multimedia yang dibuat semenarik mungkin agar para pemain bisa mendapatkan kepuasan batin saat bermain [6]. Game dibuat dengan bentuk dan cara bermain yang berbeda-beda. Dalam pembuatan game tingkat kesulitannya dapat bervariasi ada yang dengan tingkat kesulitan yang sangat sederhana mudah dipahami, tingkat menengah, tingkat mahir.

\subsection{Konsep Pengembangan Game}

Konsep pengembangan game antara lain [6]:

\subsubsection{Komponen Game}

a. Narrative

Banyak permainan memiliki unsur-unsur narrative yang memberikan konteks untuk sebuah event pada game, membuat aktifitas bermain kurang abstrak dan meningkatkan nilai hiburan, meskipun unsur-unsur narrative tidak selalu ada. Contohnya tetris.

b. Gameplay

Gameplay melibatkan interaksi pemain dengan permainan, biasanya untuk tujuan hiburan, pendidikan, atau pelatihan.

c. Interaksi

Interaksi yang dilakukan dalam game adalah ketika user dapat berkomunikasi dengan user lainnya dalam waktu yang bersamaan walau tempat mengakses game tersebut berbeda. Interaksi yang dilakukan bisa saja berupa chatting pada saat bermain, atau kerja sama team dalam game tersebut, contohnya seperti game online Ayo dance, Counter-Strike (CS) dan lain-lain.

\subsection{Jenis Game}

Jenis game atau genre game merupakan gaya atau format dari sebuah game. Jenis game antara lain [6]:

a. Maze Game

Jenis game ini biasanya menggunakan maze sebagai setting atau latar game. Jenis game maze ini termasuk jenis game yang paling awal muncul. Contoh game ini adalah game Pacman dan Digger.

b. Board Game

Game jenis ini sama dengan game board tradisional seperti monopoli. Hanya saja permainan tradisional ini dimainkan melalui komputer.

c. Card Game

Jenis game kartu juga tidak jauh berbeda dengan game tradisional aslinya. Namun, tampilannya lebih bervariasi dari versi tradisional. Game ini juga termasuk game yang awal muncul. Contoh game ini adalah Solitaire dan Hearts.

\section{d. Battle Card Game}

Game ini jarang ditemukan di Indonesia. Film kartun yang bercerita permainan battle card ini pernah ditayangkan di stasiun televisi Indonesia. Contoh game ini adalah Battle Card Pokemon.

e. Quiz Game

Game jenis ini merupakan game dengan bentuk kuis. Contoh Quiz Game yang pernah beredar yaitu game kuis Who Wants To Be Millionaire.

\section{f. Puzzle Game}

Jenis game ini memberi tantangan dengan cara menjatuhkan atau melenyapkan sesuatu dari sisi atas ke bawah atau dari sisi kiri ke kanan. Contoh game ini adalah Tetris.

g. Shoot Them Up

Game jenis ini biasanya musuh berbentuk pesawat atau bentuk lain yang datang dari arah kanan, kiri, atau atas yang harus kita tembak sebanyak dan secepat mungkin. Dulu game ini berbentuk dua dimensi (2D), tetapi sekarang sudah berkembang dan menggunakan efek tiga dimensi (3D). 


\section{h. Side Scroller Game}

Pada game jenis ini pemain diharuskan bergerak searah di alur yang disediakan. Pemain diharuskan untuk berjalan, meloncat, merunduk serta menghindari rintangan-rintangan. Contoh game ini yang popular yaitu Mario Bros dan Prince of Persia.

i. $\quad$ Fighting Game

Jenis game ini sesuai dengan namanya berisi tentang pertarungan. Contoh game ini yaitu Street Fighter, Samurai Showdown, Virtual Fighter dan Kungfu.

j. $\quad$ Racing Game

Racing game adalah game tentang balapan. Contoh game ini yaitu Need for Speed Underground dan Toca Race Driver.

k. Turn-Based Strategy Game

Pemain dalam game ini melakukan gerakan setelah pemain lain melakukan gerakan jadi saling bergantian. Contoh game yang terkenal adalah Empire dan Civiliztion.

l. Real Time Strategy

Game ini seperti game Turn Based Startegy (RTS), namun pada game ini pemain tidak perlu menunggu pemain lain. Pemain tercepatlah yang akan menang. Contoh game ini yaitu Warcraft.

m. SIM

Game genre ini merupakan bentuk permainan simulasi. Di sini pemain membangun sebuah area, kota, negara atau koloni. Contoh game ini yaitu Ship Simulator, Train Simulator, dan Crane Simulator.

n. First Person Shooter

Banyak baku tembak dan game ini mengutamakan kecepatan gerakan. Contoh game ini yaitu game Counterstrike dan Doom.

o. First Person Shooter 3D Vehicle Based

p. Third person $3 D$ Games

q. Role Playing Game

Jenis game ini pemainnya memainkan sebuah tokoh atau karakter. Biasanya ada alur cerita yang harus dijalankan. Contoh game ini adalah Legacy of Kain dan Beyond Divinity.

r. Adventure Game

Adventure game merupakan genre game petualangan. Di sepanjang perjalanan pemain akan menemukan peralatan yang akan disimpan dan berguna sebagai petunjuk perjalanan. Contoh game ini yaitu Sam and Max atau Beyond and Evil.

s. Educational dan Edutainment Game

Game ini lebih mengacu pada isi dan tujuan dari game. Game ini bertujuan memancing minat belajar anak sambil bermain. Contoh game ini adalah Baby Bola

t. Sport Games

Jenis game ini bertemakan olahraga seperti pada umumnya, kita dapat mengontrol manusia diibaratkan kita sendiri di dalam game tersebut. Yang membedakan adalah kita disini adalah kita tidak benar-benar berolahraga, melainkan tokoh yang kita mainkanlah yang melakukan kegiatan tersebut. Contoh game ini adalah PES 2010, Winning Eleven.

\section{METODE PENELITIAN}

\subsection{Konteks Penelitian (Pemanasan Global)}

Pemanasan Global merupakan kejadian meningkatnya temperatur rata-rata atmosfer, laut dan daratan. Temperatur rata-rata global pada permukaan bumi telah meningkat $0,74 \pm 0,18{ }^{\circ} \mathrm{C}$ selama 100 tahun terakhir [6].

\subsubsection{Faktor - faktor penyebab terjadinya pemanasan global [7]:}

a. Polusi Karbondioksida dari pembangkit listrik bahan bakar fosil

Ketergantungan kita yang semakin meningkat pada listrik dari pembangkit listrik bahan bakar fosil membuat semakin meningkatnya pelepasan gas karbondioksida sisa pembakaran ke atmosfer. Sekitar $40 \%$ dari polusi karbondioksida dunia, berasal dari produksi listrik Amerika [8]. Kebutuhan ini akan terus meningkat setiap harinya. Sepertinya, usaha penggunaan energi alternatif selain fosil harus segera dilaksanakan [8]. Tetapi, masih banyak dari kita yang enggan untuk melakukan ini. 
b. Polusi Karbondioksida dari pembakaran bensin untuk transportasi

Sumber polusi karbondioksida lainnya berasal dari mesin kendaraan bermotor [8]. Apalagi, keadaan semakin diperparah oleh adanya fakta bahwa permintaan kendaraan bermotor setiap tahunnya terus meningkat seiring dengan populasi manusia yang juga tumbuh sangat pesat. Sayangnya, semua peningkatan ini tidak diimbangi dengan usaha untuk mengurangi dampak tersebut.

c. Gas Metana dari peternakan dan pertanian.

Gas metana menempati urutan kedua setelah karbondioksida yang menjadi penyebab terdinya efek rumah kaca [1]. Gas metana dapat bersal dari bahan organik yang dipecah oleh bakteri dalam kondisi kekurangan oksigen, misalnya dipersawahan. Proses ini juga dapat terjadi pada usus hewan ternak, dan dengan meningkatnya jumlah populasi ternak, mengakibatkan peningkatan produksi gas metana yang dilepaskan ke atmosfer bumi.

d. Aktivitas penebangan pohon

Seringnya penggunaan kayu dari pohon sebagai bahan baku membuat jumlah pohon kita makin berkurang. Apalagi, hutan sebagai tempat pohon kita tumbuh semakin sempit akibat beralih fungsi menjadi lahan perkebunan seperti kelapa sawit. Padahal, fungsi hutan sangat penting sebagai paru-paru dunia dan dapat digunakan untuk mendaur ulang karbondioksida yang terlepas di atmosfer bumi [2].

e. Penggunaan pupuk kimia yang berlebihan

Pada kurun waktu paruh terakhir abad ke-20, penggunaan pupuk kimia dunia untuk pertanian meningkat pesat. Kebanyakan pupuk kimia ini berbahan nitrogenoksida yang 300 kali lebih kuat dari karbondioksida sebagai perangkap panas, sehingga ikut memanaskan bumi [2]. Akibat lainnya adalah pupuk kimia yang meresap masuk ke dalam tanah dapat mencemari sumber-sumber air minum kita.

\subsubsection{Dampak Pemanasan Global}

Akibat terjadinya pemanasan global menimbulkan banyak dampak antara lain :

a. Kenaikan permukaan air laut seluruh dunia

Peningkatan tinggi air laut di seluruh dunia terjadi apabila dua lapisan es raksasa di Antartika dan Greenland mencair [8]. Banyak negara di seluruh dunia akan mengalami efek berbahaya dari kenaikan air laut ini [6].

b. Peningkatan intensitas terjadinya badai

Tingkat terjadinya badai dan siklon semakin meningkat dikarenakan pemanasan global secara signifikan akan menyebabkan terjadinya kenaikan temperatur udara dan lautan [1]. Hal ini mengakibatkan terjadinya peningkatan kecepatan angin yang dapat memicu terjadinya badai kuat.

c. Menurunnya produksi pertanian akibat gagal panen

Pemanasan global memicu terjadinya perubahan iklim yang kurang kondusif bagi tanaman pangan.sehingga memungkinkan terjadinya bencana kelaparan karena faktor menurunnya produksi pangan pertanian akibat kegagalan panen [2].

d. Makhluk hidup terancam kepunahan

Peningkatan suhu dapat menyebakan terjadinya kepunahan jutaan spesies. Artinya, di tahun-tahun mendatang keragaman spesies bumi akan jauh berkurang.

\subsubsection{Tindakan Pencegahan Pemanasan Global}

Banyaknya dampak yang ditimbulkan akibat dari pemanasan global membuat kita harus segera melakukan tindakan untuk segera mengatasinya. Cara atau tindakan yang dapat mencegah terjadinya pemanasan global antara lain [1] :

a. Jangan menebang pohon sembarangan

Pohon merupakan penghasil gas $\mathrm{O} 2$ (oksigen) terbesar di dunia. setiap hari kita bernafas membutuhkan Oksigen,dan pohon-pohonlah yang setiap harinya menyediakan oksigen untuk kita. Semakin sedikit pohon akan menyebabkan gas $\mathrm{CO}_{2}$ (karbondioksida) bisa dengan leluasa berkeliaran dan akhirnya membuat bumi semakin panas [2]. Terlepas dari itu kita bernafas menggunakan oksigen tanpa adanya oksigen mungkin kita tidak akan bisa hidup sampai sekarang.

b. Kurangi menggunakan kendaraan pribadi

Banyaknya pemakaian kendaraan pribadi akan menyebabkan borosnya penggunaan bahan bakar. Setiap kendaraan berbahan bakar minyak akan mengeluarkan gas pembuangan berupa $\mathrm{CO}_{2}$ dan $\mathrm{CO}$, gas-gas ini bila dalam jumlah yang besar dapat menimbulkan efek gas rumah kaca yang akhirnya membuat terjadinya global warming semakin parah [8]. 
c. Beralih dari kendaraan berbahan bakar minyak dengan kendaraan berbahan bakar alami dan ramah lingkungan [8].

d. Melakukan reboisasi (penanaman kembali hutan yang gundul) [2].

e. Membangun rumah dengan fentilasi yang cukup [1].

\subsection{Metode Pengumpulan Data}

Penelitian ini merupakan penelitian terapan. Pengumpulan data dimulai dengan membagikan quisioner pada 10 civitas akademik di sekolah TK dan SD dikabupaten klaten secara random. Pembagian quisioner ini bertujuan untuk mengetahui seberapa jauh pemahaman pengajar dan anak didik mereka terhadap pemanasan global dan akibatnya. Observasi juga dilakukan terhadap beberapa sekolah TK dan SD dengan mencatat hasil pengamatan sikap dan tindakan anak anak TK dan SD dalam menjaga kelestarian lingkungan disekitar mereka serta bagaimana civitas akademik di TK dan SD mengajarkan hal tersebut ke anak anak.

\subsection{Metode Pengolahan Data}

Dari data hasil observasi dan quisioner, game dengan genre edukasi dipilih sebagai media yang menarik dan menyenangkan untuk melakukan pembelajaran tentang pemanasan global [9]. Game ini terdiri 3 level yaitu level 1 tentang jangan menebang pohon sembarangan, level 2 tentang penanaman pohon (reboisasi), level 3 tentang penggunaan rumah hemat energi dengan menggunakan fentilasi rumah yang cukup dan pengggunaan bahan bakar alami pada kendaraan bermotor. Perancangan konsep dan isi game dilakukan dan dapat digambarkan dalam arsitektur game sebagai berikut :

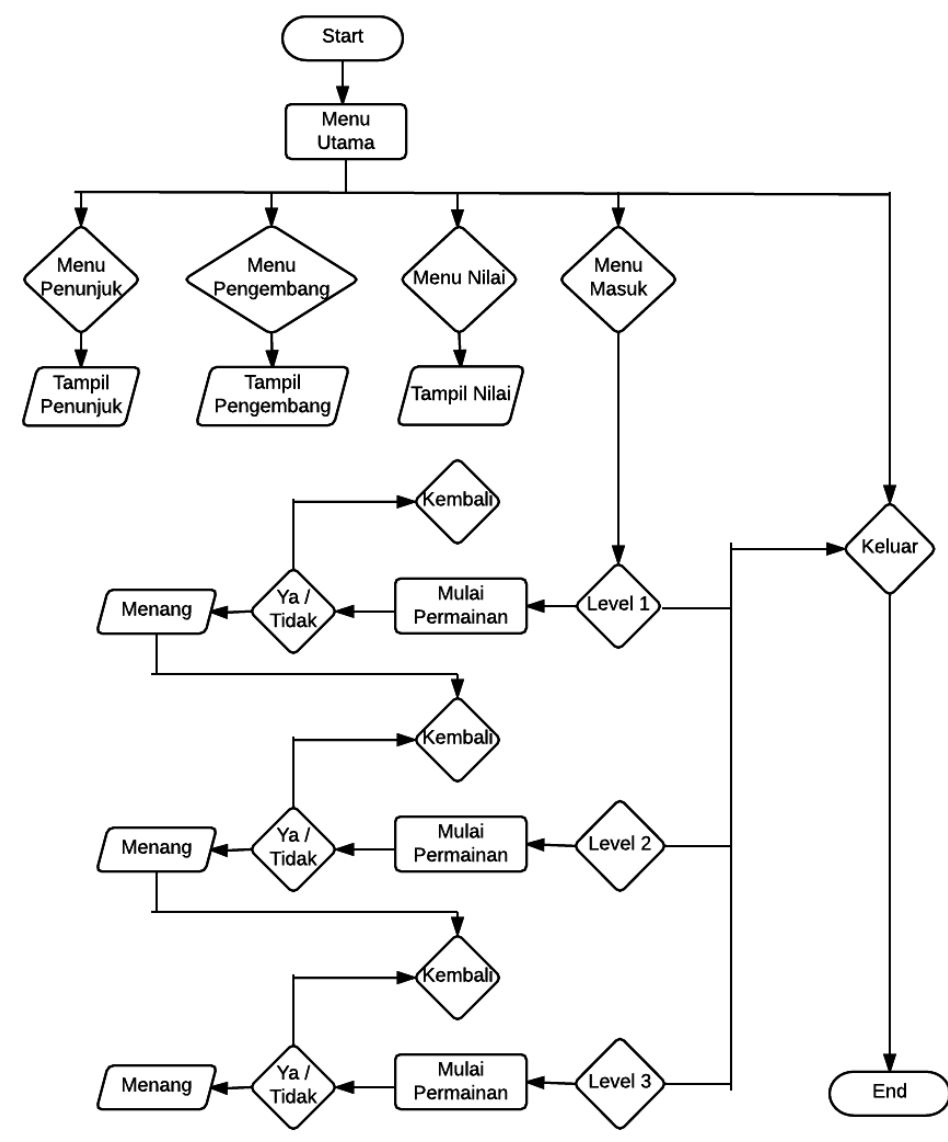

Gambar 1. Arsitektur Game Interaktif

Game edukasi ini dimulai dari tampilan menu utama / awal terlebih dahulu yang terdapat lima tombol yaitu tombol petunjuk, tombol pengembang, tombol nilai, tombol masuk, dan tombol keluar. Setelah masuk ke dalam permaianan maka akan masuk ke level 1 terlebih dahulu kemudian ke level 2 dan ke level 3 jika level sebelumnya sudah terselesaikan. Jika sudah keluar atau kembali ke menu utama maka 
saat masuk game ini akan lansung masuk dimulai dari level 1 terlebih dahulu secara berurutan sampai level 3.

Dalam pembuatan game mencegah terjadinya pemanasan global ini, langkah awalnya adalah memasukkan atau menyiapkan aset-aset di library Flash yang akan digunakan untuk bekerja. Contoh aset-aset yang perlu disiapkan dalam membuat game ini seperti gambar background, pohon, mobil, mobil berasap, dan gambar lainya. Aset Aset library antara lain seperti pohon, penebang, pot tanaman, mobil, tanaman. Aset - aset library dapat dilihat seperti gambar berikut :
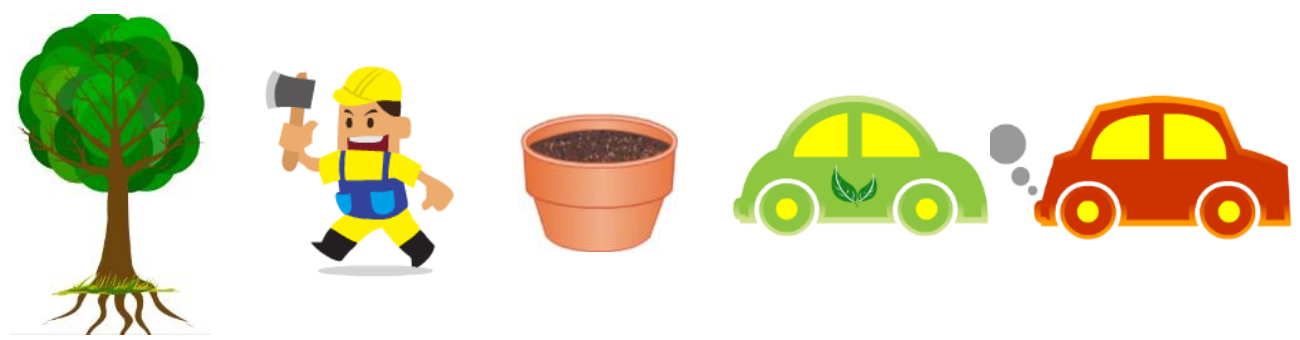

\section{Gambar 2. Aset - aset library}

Langkah berikutnya adalah membuat desain gambar background baik ditampilan permainan maupun ditampilan - tampilan yang lain. Desain background yang diperlukan adalah desain background menu, desain background level 1, 2 dan level 3. Desain background menu digambarkan dengan pemandangan sawah yang hijau. Desain background level 1 digambarkan dengan hutan diluar kota dengan aset library seperti pohon. Desain background level 2 digambarkan dengan papan yang berjalan dengan aset library pot tanaman yang siap untuk dijadikan media tanam bagi tumbuhan baru yang akan ditanam. Desain background pada level 3 digambarkan dengan suasana jalan ditengah kota dengan aset library berupa mobil yang mengeluarkan asap. Desain background dalam game tersebut digambarkan sebagai berikut :
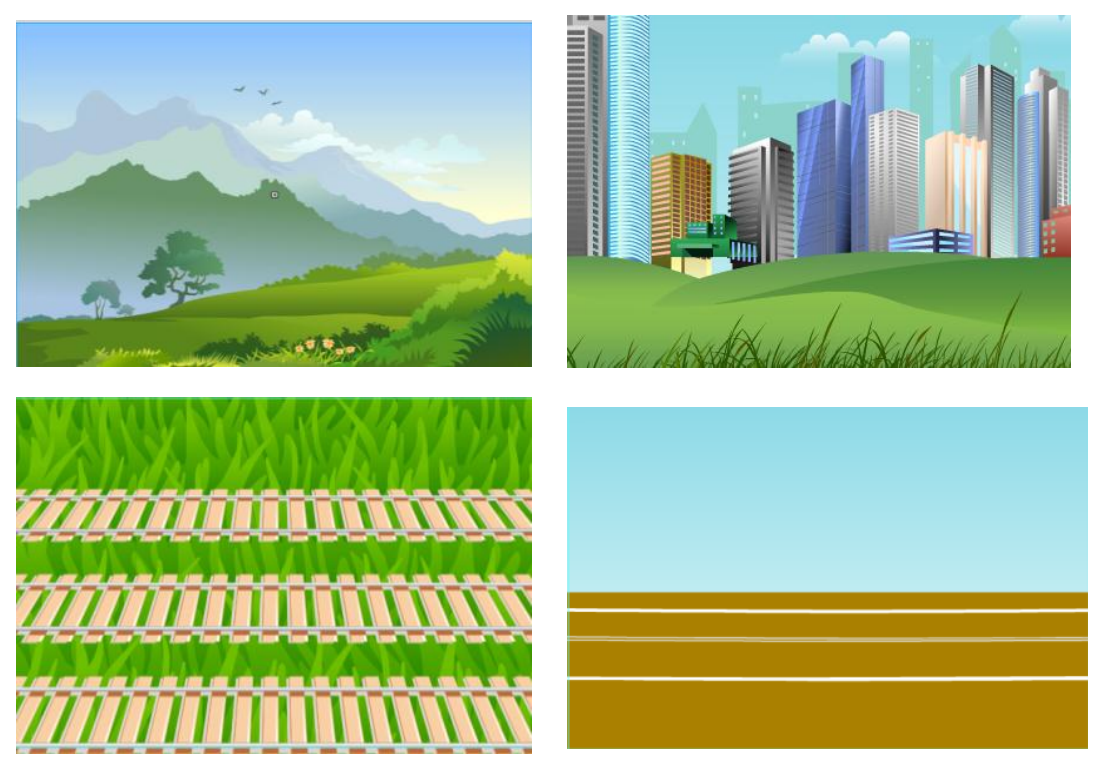

Gambar 3. Background

Tahapan berikutnya adalah pembuatan animasi yang nantinya akan di tampilkan dalam game seperti animasi orang yang akan menebang pohon di level 1, animasi pot tanaman yang berjalan di level ke 2 dan animasi mobil yang mengeluarkan asap di level yang ke 3. Setelah itu menambahkan script atau perintah untuk menjalankan game antara lain seperti script pada orang yang akan menebang pogon, pot tanaman, mobil yang mengeluarkan asap, score nilai dan lain lain. Tahapan berikutnya adalah test aplikasi untuk melihat hasilnya dimana hasil aplikasi sudah dikonversi dalam bentuk file .exe. Pembuatan game pemanasan global ini menggunakan software aplikasi adobe flash CS 5 dengan action scriptnya adalah action script 3.0 [10].

\section{HASIL PENELITIAN DAN PEMBAHAHASAN}

Tampilan game mencegah terjadinya pemanasan global ini sebagai berikut: 
a. Tampilan Menu Utama

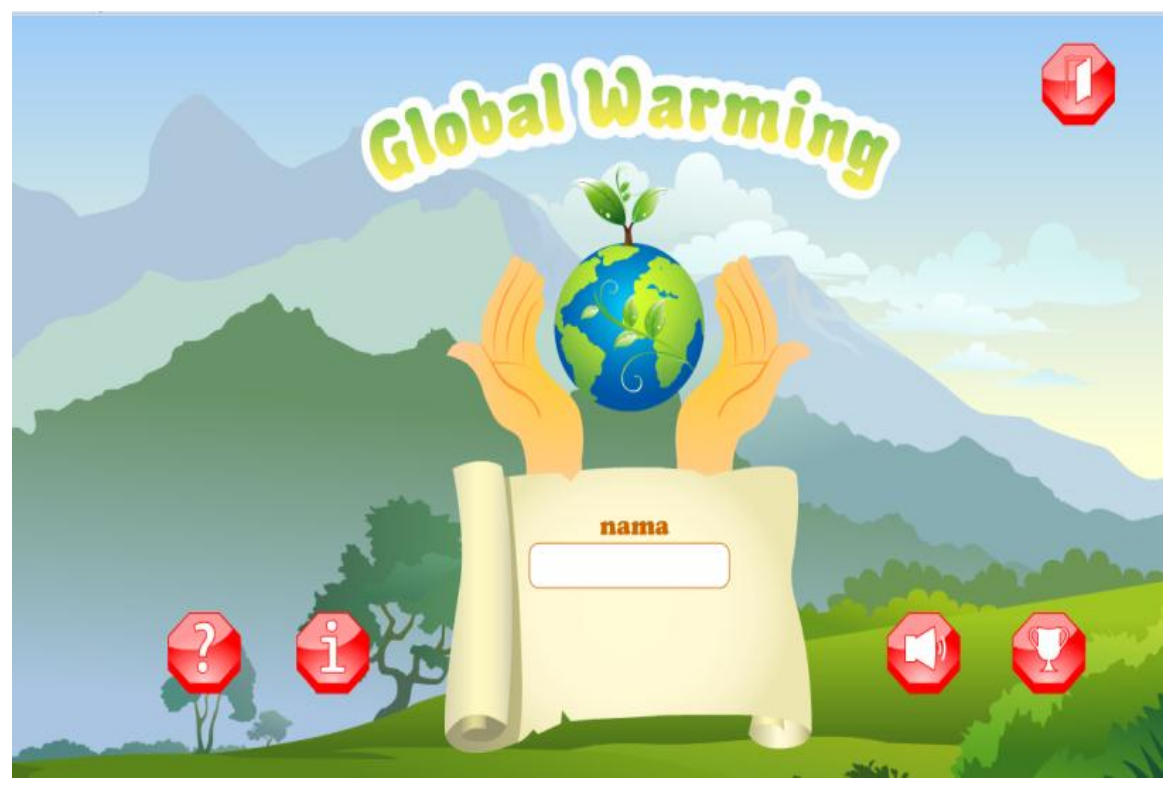

Gambar 4. Tampilan Menu Utama

Script tampilan menu utama sebagai berikut :

package

\{

import flash.display.MovieClip;

import flash.events.Event;

import flash.events.MouseEvent;

public class AwalScreen extends MovieClip

\{

public var exitS:ExitScreen;

public function AwalScreen()

\{

focusRect $=$ false;

$\mathrm{x}=450$;

$\mathrm{y}=300$;

addEventListener(Event.ADDEDTOSTA.GE, init);

\}

private function init(e:Event);void

\{

removeEventListener(Event.ADDEDTOSTAGE, init);

addFrameScript $(0$, framel, 77, frame 78);

\} 
b. Tampilan Level 1
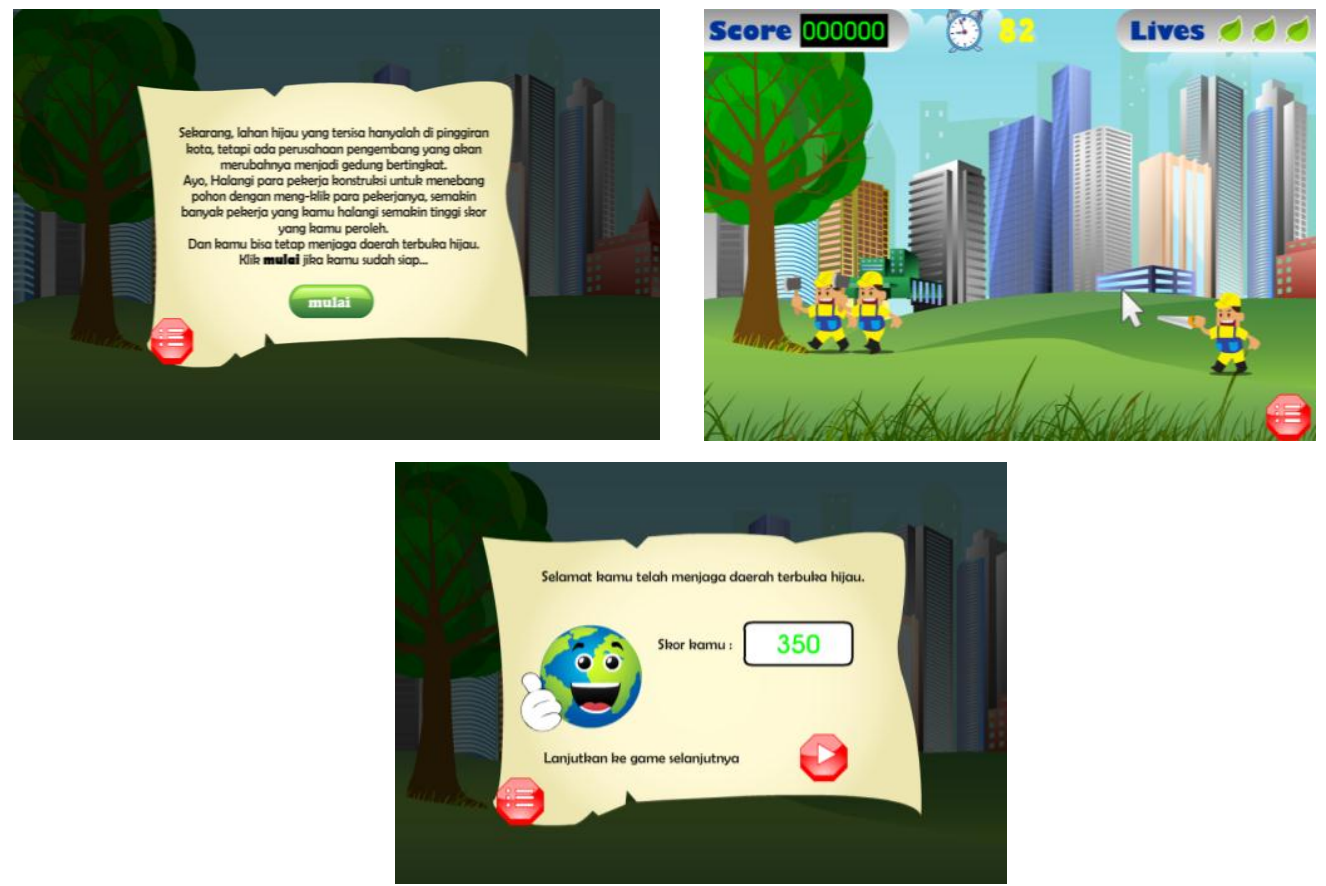

Gambar 5. Tampilan Level 1

Script tampilan level 1 sebagai berikut :

package

\{

import Enemy. Orangl;

import Enemy.Orang2;

import Enemy.Orang3;

import Enemy.Orang4;

import Enemy.OrangHilang;

import flash.display.MovieClip;

import flash. events. Event;

import flash.events.MouseEvent;

import flash. events. TimerEvent;

import flash.utils.Timer;

public class PlayScreen1 extends MovieClip

\{

public var gamePohon: PohonMC;

public var gameTime:PapanTime;

public var gameSkor:PapanSkor;

public var gameNyawa: PapanNyawa;

public var CurrentNyawa:Number;

public var count:Number;

public var gameTimer:Timer;

public var musuhTimer:Timer;

public var army:Array;

\}

\} 
c. Tampilan Level 2
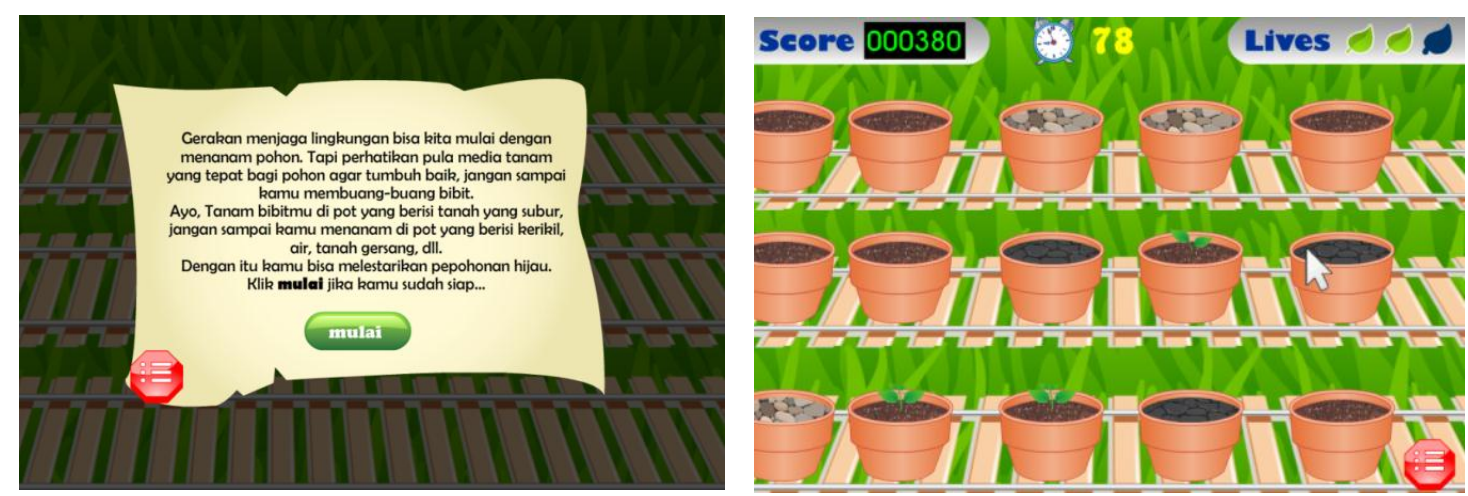

Gambar 6. Tampilan Level 2

d. Tampilan Level 3

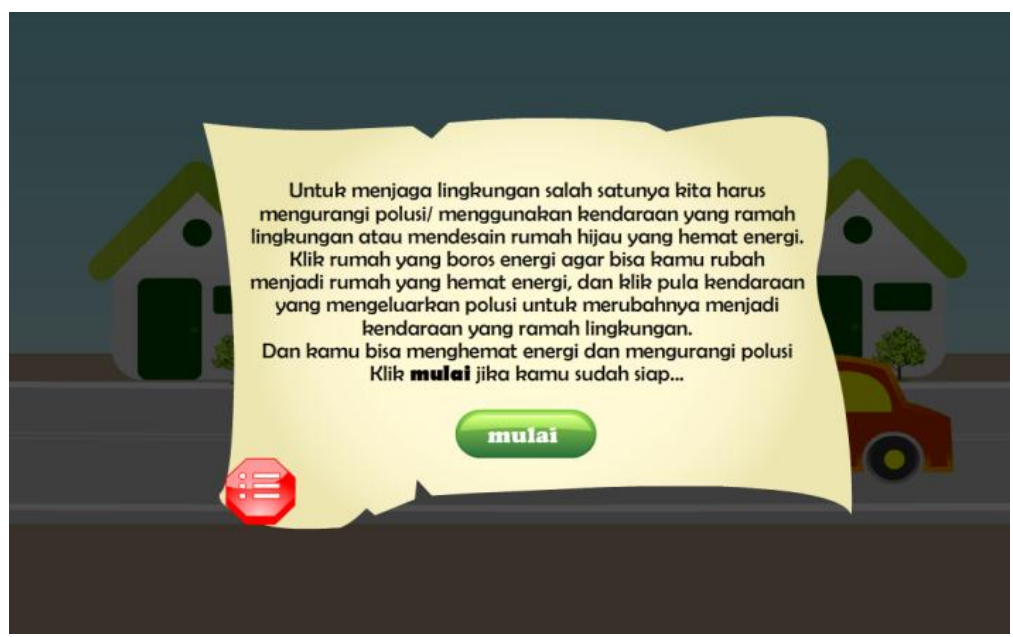

Gambar 7. Tampilan Level 3

Script tampilan level 3 sebagai berikut :

package

\{

import flash.display.MovieClip;

import flash. events. Event;

import flash.events.MouseEvent;

import flash. events. TimerEvent;

import flash.utils.Timer;

import Pot.Potl;

import Pot.Pot2;

import Pot.Pot3;

import Pot.Pot4;

import Pot.ReINC;

public class PlayScreen2 extends MovieClip

public var gameTime:PapanTime;

public var gameSkor:PapanSkor;

public var gameNyawa: PapanNyawa;

public var CurrentNyawa:Nurdoer;

public var count:Number;

public var gameTimer:Timer; 
public var potTimer:Timer;

public var rel:ReIMC;

public var posXAwalRel:Number;

\})

Dalam game ini akan terdapat 5 menu antara lain : menu utama (play) yang akan muncul saat tulisan nama sudah dimasukkan, menu petunjuk merupakan menu yang menjelaskan tentang simbol - simbol yang digunakan dalam game, menu pengembang adalah menu yang berisi tentang profil pengembang game, menu suara adalah menu yang mengatur suara on/off dalam game, menu nilai adalah menu yang berisi tentang lima nilai tertinggi yang bermain dalam game. Nilai tersebut akan tetap tersimpan dalam game walaupun kita sudah keluar dari program game yang sudah dijalankan.

Game mencegah pemanasan global setiap levelnya ditentukan oleh durasi waktu. Kecepatan pekerja penebang pohon, pot tanaman, lampu rumah dan kendaraan pada setiap level berbeda beda. Semakin tinggi level maka kecepatannya semakin cepat. Pada level 1 tentang jangan menebang pohon sembarangan, dimana dalam level ini setiap penebang yang dapat dihalangi akan mendapatkan skor 10. Pada level 2 tentang penanaman pohon (reboisasi), dimana setiap pemberian bibit pada pot yang benar akan mendapatkan skor 10. Sedangkan pada level 3 tentang penggunaan rumah hemat energi dengan menggunakan fentilasi rumah yang cukup dan pengggunaan bahan bakar alami pada kendaraan bermotor dimana terdapat dua tantangan yaitu mengganti rumah menjadi hemat energi dan kendaraan yang ramah lingkungan.

\section{KESIMPULAN}

Pemanasan global merupakan kenaikan suhu bumi yang mengakibatkan banyak dampak yang negatif. Hal ini perlu diatasi dengan tindakan yang tepat. Salah satunya dengan menanamkan kesadaran diri pada anak - anak secara dini tentang perlunya menjaga kelestarian lingkungan sekitar dan akibat dari pemanasan global. Penanaman kesadaran dapat dilakukan dengan melakukan pembelajaran yang menyenangkan bagi anak - anak. Game Interaktif mencegah pemanasan global ini dapat dijadikan salah satu alternatif yang efektif untuk memberikan pembelajaran yang menyenangkan ke pada anak - anak sembari bermain tentang pemanasan global, akibat yang ditimbulkan dari pemanasan global dan menanamkan rasa mencintai dan melestarikan lingkungan.

\section{DAFTAR PUSTAKA}

[1] Matthews, H. D., Graham, T. L., Keverian, S., Lamontagn, C., Seto, D., \& Smith, T. J. (2014). National Contributions to Observed Global Warming. Environmental Research Letters .

[2] Truelove, H. B., \& Parks, C. (2012). Perceptions of behaviors that cause and mitigate global warming and intentions. Elsevier Journal of Environmental Psychology , 246-259.

[3] R, A. N., E, K. A., P, M. A., \& S, M. A. (2009). Characterization Factors for Global. Enviromental Science \& Technology, 1689-1695.

[4] Maillot, P., Perrot, A., \& Hartley, A. (2012). Effects of Interactive Physical-Activity Videogame Training on Physical and Cognitive. American Psychological Association, 589-600.

[5] Hung, C.-Y., Member, S., IEEE, Kuo, F.-O., Sun, J. C.-Y., \& Yu, P.-T. (2014). An Interactive Game Approach for Improving Students' Learning Performance in Multi-Touch Game-Based Learning. IEEE Transaction on Learning Technologies , 31-37.

[6] Suarsana, M. d. (2011). Global Warming. WIDYATECH Jurnal Sains dan Tehnologi , 31.

[7] Strefler, J., Luderer, G., Kriegler, E., \& Meinshausen, M. (2014). Can air pollutant controls change global warming? Elsevier Environmental scienc e \& policy , 33-43.

[8] Susanta, G. (2008). Akankah Indonesia Tenggelam Akibat Pemanasan Global. PenebarPlus.

[9] Dra.Entit Usidati, S. (2010). Game sebagai media pembelajaran masa kini. Harian Gala Media.

[10] Peter, K. (2007). Foundation ActionScript 3.0 Animation. San Faransisco: Friendsof 